\title{
PRINCIPAL'S STRATEGIES IN REALIZING ADIWIYATA SCHOOL: A LITERATURE REVIEW
}

\author{
Andina Wijayanti, Hasan Hariri, Dedy Hermanto Karwan, and Sowiyah \\ Lampung University \\ E-mail: andinawijayanti1983@gmail.com, hasantownsville@gmail.com, \\ dedy.karwan@fkip.unila.ac.id, sowi.unila@gmail.com
}

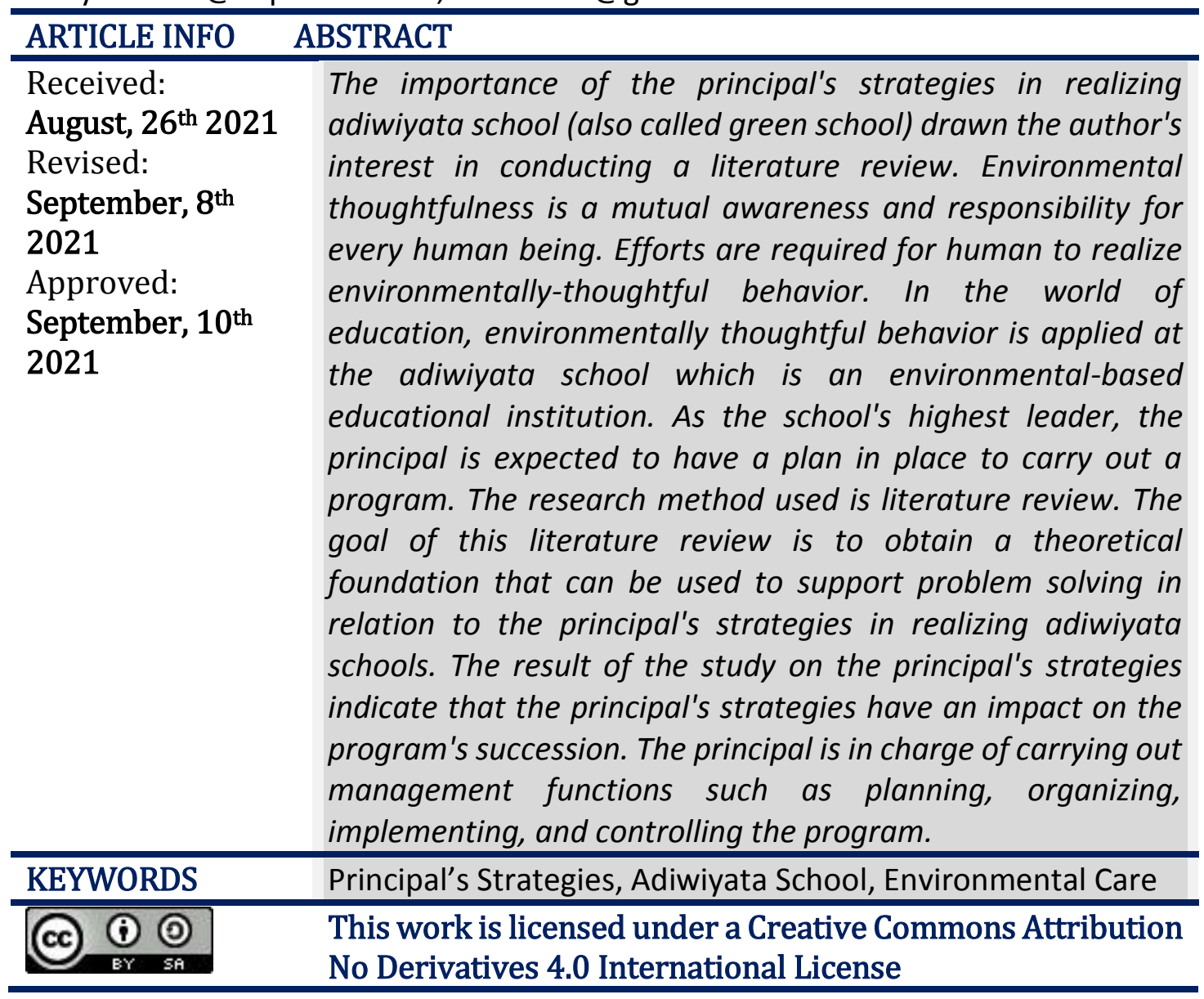

INTRODUCTION

\begin{tabular}{ll}
\hline & Andina Wijayanti, Hasan Hariri, Dedy Hermanto Karwan, and Sowiyah. \\
& (2021) Principal's Strategies In Realizing Adiwiyata School: A Literature \\
& Review. Journal Eduvest. 1(9): 841-849 \\
How to cite: & $2775-3727$ \\
E-ISSN: & https://greenpublisher.co.id/ \\
Published by: &
\end{tabular}




\section{Andina Wijayanti, Hasan Hariri, Dedy Hermanto Karwan, and Sowiyah}

In Indonesia, and even overseas, the living environment is a mutual issue and concern. In Indonesia alone, environmental issues becomes a fundamental issue that is currently developing (Miranto, 2017). Environmental issue is not a new thing, but an issue as old as our earth itself that, according to the expert, is about five billion years old (Mukminin, 2014). This issue generates a variety of effects that can have a direct impact on nature, and these effects are not only temporary but can have long-term consequences. Further worrying consequences are symptoms of global warming and climate change related to the greenhouse effect, crop damage, forest loss, and species extinction, reduced fish resources, agricultural land, air and water supplies pollution (Oskamp, 2000).

Environmental issues must now be addressed immediately and this become the responsibility of all parties, including the community and policymakers. Various methods are used to mitigate the effects of the environmental damage. One of them is the requirement for moral and ethical improvement in order to effect changes in attitudes and behavior in society, specifically through education (Basri, 2018). Earth, being the only human habitat, will be passed to the younger generation in the future, and their awareness of the importance of environmental protection is a kind of personal and societal responsibility. With education, there are hope that they have the awareness of environmental protection (Afandi, 2013). Education contributes to the development of abilities, personality, character, and national dignified civilization by instilling environmental education values in the nation's next generation (Widyaningrum, 2016). Environmental education is one of the important factors in environmental management succession, as well as a critical tool in developing human resources capable of implementing the principles of sustainable development (Landriany, 2015). Environmental education is implemented in order to increase the public understanding and concern in finding solutions and preventing the emergence of environmental issue (Adam, 2014). Through teaching and learning process that includes environmental education, the provision of comfortable school environment, and school facilities that allow or support students in awakening, directing, and guiding them toward the formation of environmental ethics (Mulyana, 2009). Changes in human perspective and behavior cannot be detached from the formation of citizens' ethics and morality. The formation of ethics and morality is the primary goal of education implementation in Indonesia, as stated in the national education goals contained in Law Number 20 of 2003 concerning the National Education System, which states that national education functions to develop and shape the character and civilization of a dignified nation in the context of the nation's intellectual life, aims to develop students' potential as human beings who believe and fear god almighty, have noble character, healthy, knowledgeable, capable, creative, and independent, and become democratic and responsible citizens (Aulia, Arif, \& Arpannudin, 2018).

School plays an important role in instilling moral values and environmental thoughtfulness. Adiwiyata is an environmental education development program for primary and secondary school students that has been in place since 2016 (Rezkita \& Wardani, 2018). Adiwiyata School is an educational institution founded on love for the environment, with the goal of instilling environmental thoughtfulness in students (Rahmawati \& Suwanda, 2015). A good school environment aims to create a conducive learning environment and raise awareness among school members to take responsibility in efforts to save the environment and promote sustainable development (Pradini, Sudjanto, \& Nurjannah, 2018). Improving the quality of education through learning to support the swift operation of development in Indonesia as a whole is a critical role for schools as formal educational institutions (Djafri, 2020).

The reduction of environmental issues are expected as there are increasing number of schools implementing environmental care programs or green schools (Olsson, 2018). 
The approval of the Environmental Education policy by four agencies/ministries, namely the State Ministry for the Environment, the Ministry of Culture and Tourism, the Ministry of Religion, and the Ministry of Home Affairs, is one of the Indonesian government's efforts to achieve national development in environmental education. Population and Enviromental Education, Enviromental Education, Environmentally Cultured School and Green School are used from elementary school to the university (Astuti, 2015).

Therefore, the government is trying to increase the number of adiwiyata schools (Hidayati, 2014). From 2006 to 2011 there were only 1,351 schools participating in the adiwiyata program from 251,415 schools (elementary school, junior high school, senior high school, vocational high school) throughout Indonesia, including those who received independent adiwiyata: 56 schools, adiwiyata: 113 schools, adiwiyata candidates 103 schools, or the total who received the adiwiyata award reached 272 schools (elementary school, junior high school, senior high school, vocational high school) throughout Indonesia (Tim Adiwiyata Tingkat Nasional, 2011). According to the US Green Buildings Council's Center for Green Schools, a green school is defined as a building or school facility that creates a healthy environment conducive to learning while also saving energy, resources, and money. In Ireland, Green schools, also known as Eco-Schools are international environmental education programs that include environmental management systems and award schemes to promote their long-term environmental sustainability initiatives. On the other hand, Institutopara o Desenvolvimento da Habitacao Ecologica (IDHEA) claims that green schools are constructions that are developed based on more sustainable environmental planning by utilizing natural resources, efficient waste management, and rationalizing the use of available materials for sustainability (Lee \& Burnett, 2008).

Schools as formal educational organizations have internal personnel in their organizations consisting of principals, teachers, employees and students (Purwanti, 2013). Organizational sustainability is the Principal's responsibility as the leader (Setiyati, 2014). The principal plays an important role in the school's succession. The presence and competence of a leader is the heart of organizational management. A leader must instill positive change in their personal by encouraging them to take the initiative and change (Quin, Deris, Bischoff, \& Johnson, 2015). The principal's strategies has a significant impact on increasing teachers' motivation to perform their duties at school (Aksiadi \& Gumilar, 2020). Whereas the goal of strategies implementation in an organization is as a means in order to achieve the final results by developing specific policies and techniques to achieve these goals and being able to ensure their proper implementation (Khrisnamurti, 2019).

Every citizen bears responsibility in environmental sustainability management. One of the simplest places to implement environmental conservation is in the field of education. With environmentally friendly facilities, environmentally sound curriculum and policies, the school becomes a good place for learning, so that all of the school members have a stake and responsibility in efforts to save the environment. Both teachers and students should have competence in the development of enviromental learning. This can be accomplished through the principal's role as the highest leader in educational institutions, as well as the preparation of strategic steps. Effective principals can compose strategies for planning, coordinating, mobilizing, and directing teachers, staff, students, and even the community in the school setting. However, there are few literature studies on this topic, particularly on the principal's strategies. As a result, a literature review will be conducted in this review paper. 


\section{RESEARCH METHOD}

The research method used is literature review. The purpose of this literature review is to obtain a theoretical basis that could support in resolving an issue. Review process begins with a searchon search engine; Google Scholar, for articles containing these keywords; "Principal's Strategies" and "Adiwiyata Program". Search ranged from article that are published between $2000-2020$, and identifying 200 study and article related to stated keyword. The criteria of inclusion in this study are:

a. Qualitative and quantitative result of "Strategies of Adiwiyata School's Principal"

b. Research from various country in the world

c. Research article are written in English and Indonesian

d. Dissertation and thesis are excluded

The steps in this literature review are:

Step 1: Define the issues

- Choose a topic that is relevant to the issues and interest

- The issues must be written completely and accurately

Step 2: Look through the literature

- Search for literature that is relevant to the research

- Get an overview of the research topic

- Research sources will be convenient if supported by knowledge related to the topic that being studied.

- The sources must provide an overview/summary related to previous research.

Step 3: Data evaluation

- Attend to the contribution made by article to the topic

- Attend to the contribution of article related to the topic

- Data can be quantitative data, qualitative data, or a combination of both

Step 4: Analysis and interpretation

- Discuss and summarize the literature.

\section{RESULT AND DISCUSSION}

\section{A. Adiwiyata Program}

Global warming is the process of average temperature rises of the atmosphere, sea, and land of earth. This rising temperature of earth is caused by growing concentration of greenhouse gasses as a result of human activity. With the presence of global warming, a lot of damages are caused; not only one, but those could reach the entire of earth's structure. This increase in global temperature will cause numerous changes such as extreme weather, uprising sea level, extinction of various kinds of animals, impinge on agricultural output, loss of glaciers and melting of the ice in North and South Pole (Wuryandari \& Akmaliyah, 2016).

Currently, the huge impact of global warming can be felt clearly, starting of the uprising temperature to unpredictable weather without the need to studying it intensively. But understanding of the proper basic concept of global warming need to be emphasized to student from the early age, so that they understand any of the impact that happen due to the process of global warming, so they can determine the right countermeasure to deal with global warming (Asfuriyah \& Nuswowati, 2015). Various cases of environmental damages that have occurred both globally or locally, if to be collectively understood, actually rooted from human's view and attitude towards their natural environment. Human's behavior that 
lacks of awareness and responsibility for the environment have caused imbalance and damage. Based on this problem, to form a character who loves the environment, the government tries to create an environment-based education. The implementation of environment-based education is carried out with environment-based education or adiwiyata school (Aprilia, 2016).

Adiwiyata is one of the program of the State Ministry for the Environment that aims to induce the creation of citizen's knowledge and awareness in order to conserve the environment (Fitria \& Samsia, 2020). This in where it is necessary to develop the implementation of environment-based school education, because environmental maintenance are the responsibility of all citizen and an integral part of learning in school, both through intracurricular and extracurricular programs. The implementation of environment-based school is an effort to open the insights and basic environmental management as well as to raise awareness to overcome the broad variety of environmental issues (Dasrita, Saam, Amin, \& Siregar, 2015).

Adiwiyata School is one of the programs of the State Ministry of the Environment to encourage the development of knowledge and awareness of environmental conservation among school residents. As a program with the target of formal education at the elementary, junior high and high school levels, this program explains how to make school members care and cultured towards the environment by creating good environmental conditions as a forum for learning and awareness of all school members for the creation of environmental conservation efforts (Kristiawan, Maryanti, \& Fitria, 2019). According to the Regulation of the State Ministry for the Environment No.2/2009 Article 1 concerning the Guidelines for the Implementation of Adiwiyata Program that 1) Adiwiyata is a good and ideal school as a place to obtain a variety of knowledge and norm and ethics that can be human this towards the creation of a welfare and the idea of sustainable development; 2) Adiwiyata program is one of national work programs managed by the State Ministry for the Environment in order to realize the development of environmental education; 3) Minister is the minister who carries out government's affairs in the field of environmental management.

\section{B. Principal's Strategies}

Strategies comes from the Greek strategos, which means 'army', while 'ago' means 'to lead'. At first strategies was used in the military to gain victory in battles against the enemy. The term strategic planning in management emerged in the 1950s and was popular in the 1960s to 1970s. From several existing definitions, it can be concluded that strategies is a general approach that is long term (Suriansyah, 2015). The principal is a leader who plays an important role in the development and control of educational institutions. In this case, the principal's role as a manager in improving educational quality must be maximized so that he can influence staff and teachers both directly and indirectly. Furthermore, school principals play a significant role in improving educational quality in these institutions (Rosyadi \& Pardjono, 2015). The principal is a school leader who is responsible for empowering all existing resources in the school to achieve school goals. As a result, the principal is an important factor that has a large influence in moving schools toward common goals as an education leader (Sriwahyuni, Kristiawan, \& Wachidi, 2019). The Principal's strategies is one of the most important factors in efforts to improve school quality. These efforts are carried out by designing, implementing, and performing strategic steps in school management that include all elements of the school and the surrounding community. In order to implement these strategic steps, the principal must not only implement and perform, but also assess its succession, with the expected result being a rise in school quality (Murniati \& Harun, 2015). 


\section{Andina Wijayanti, Hasan Hariri, Dedy Hermanto Karwan, and Sowiyah}

\section{Discussion}

Based on the results of a review of various articles obtained, the results of the analysis show that most of the articles focus on the principal's strategy and the adiwiyata program. Table 1. shows that research related to this topic has been carried out in various educational institutions from various countries. The results of the majority of research indicate that it is difficult to find literature that combines the two variables so that the author will explain the findings for each variable.

The rationale of this article is to find out the principal's strategy in realizing Adiwiyata schools. In order to carry out its roles and functions, the principal must have the right strategy to empower educators and education staff through collaboration and encourage the involvement of all educators and education staff in various activities that support school programs. The results of the study on the principal's strategy show that the principal's strategy has an impact on success in realizing a program. This is explained by Dimas Ayu Khrisnamurti that strategy is a large, long-term plan that is increasing, efficient, and productive in order to streamline the achievement of goals developed in detail in the form of operational tactics accompanied by targets and measurable steps. The purpose of strategy in an organization is as a means to achieve final results by formulating certain policies and techniques to achieve these goals and being able to ensure their proper implementation (Khrisnamurti, 2019) To achieve this goal, according to Sri Setiyati, the Principal as the leader who is responsible for the continuity of the organization carries out business management and school development through administrative, management and leadership activities. In connection with that, it can be said that the principal as an administrator functions to plan, organize, direct, coordinate and supervise all educational activities held in a school (Setiyati, 2014). The findings of this study support Basri's findings which state that school principals implement management functions ranging from planning, organizing, implementing and controlling the programs to be run (Basri, 2018).

Another finding in this study related to principals' leadership by Roch Aksiadi and Aris Gumilar shows that leadership style affects principal's leadership effectiveness. The principal is an individual who is required to be able to transform his abilities through guidance, guidance and empowerment to all school members in order to achieve optimal school goals (Aksiadi \& Gumilar, 2020). The quality of the school is largely determined by the principal. Jeff Quin, Aaron Deris, Greg Bischoff \& James T Johnson stated that principals in high-performing schools were more likely to apply all leadership practices than principals in low-performing schools (Quin et al., 2015). It can be concluded that the principal has a very important and strategic role by implementing the management function in an effort to achieve school programs.

The results of the study on adiwiyata schools show that schools that receive the title of adiwiyata are considered to have succeeded in forming a caring character for the environment (Mukminin, 2014). That character education cares for the environment must be given to children from an early age through habituation. Where the character of caring for the environment has a positive impact on environmental awareness. It seems that what Pradini stated in his research that character building through programs implemented in adiwiyata schools shows several programs related to adiwiyata school indicators such as policies on the environment as outlined in decrees and integrated into each lesson, daily activities without plastic, bringing drinking bottles and eating containers from home, healthy canteens, availability of supporting infrastructure, processing of waste banks in $3 \mathrm{R}$ (reduce, reuse, recycle) efforts, making biopore infiltration holes and making adiwiyata monument (Pradini et al., 2018). So in her findings, Ellen Landriany stated that in order to 
realize a school program that cares and is environmentally cultured, a school management model that supports the implementation of environmental education is needed, such as environmental policies that are environmentally sound and set out in decrees and are integrated in subjects, socialization to school residents, and the provision of environmentally friendly facilities and infrastructure (Landriany, 2015).

The reviews in this literature review have limitations including the articles that are reviewed predominantly from Indonesia and the UK so that other studies are not reviewed due to limitations, dissertations and theses are excluded in this article and the scope of the articles reviewed is still very limited and it is difficult to find literature that combines the two variables.

\section{CONCLUSSION}

Apart from the limitations of the literature, the findings in this literature review are expected to contribute to the principal's strategy in realizing Adiwiyata schools. Based on the findings, it can be concluded that in order to achieve a goal in the institution/organization, a leader in this case the principal must have a strategy, namely the method used in directing all capabilities of all existing resources in an organization in the form of planning, organizing, implementing and control.

This review is still very limited and even difficult to find literature that combines the variables of principal strategy and adiwiyata program. Given that there is still little research that combines the two regarding the principal's strategy in realizing adiwiyata schools, an understanding of the principal's strategy in realizing adiwiyata schools requires further discussion.

\section{REFERENCES}

Adam, A. F. B. (2014). Analisis implementasi kebijakan kurikulum berbasis lingkungan hidup pada program adiwiyata mandiri di SDN Dinoyo 2 malang. Jurnal Kebijakan dan pengembangan pendidikan, 2(2).

Afandi, R. (2013). Integrasi pendidikan lingkungan hidup melalui pembelajaran IPS di sekolah dasar sebagai alternatif menciptakan sekolah hijau. PEDAGOGIA: Jurnal Pendidikan, 2(1), 98-108.

Aksiadi, R., \& Gumilar, A. (2020). Studi Gaya Kepemimpinan Kepala Sekolah Dalam Mengelola Sekolah Adiwiyata di SMPS Ehipassiko School BSD Kota Tangerang Selatan JMB: Jurnal Manajemen dan Bisnis, 9(1), 31-42.

Aprilia, N. (2016). Evaluasi pengelolaan sarana pendukung yang ramah lingkungan pada program adiwiyata di SMP Muhammadiyah di Kota Yogyakarta. Research Report.

Asfuriyah, S., \& Nuswowati, M. (2015). Pengembangan majalah sains berbasis contextual learning pada tema pemanasan global untuk meningkatkan minat belajar siswa. Unnes Science Education Journal, 4(1).

Astuti, F. (2015). Implementasi program adiwiyata dalam pengelolaan lingkungan sekolah dan tingkat partisipasi warga sekolah di SMP Kabupaten Wonosobo Tahun 2015. Edu Geography, 3(8).

Aulia, S. S., Arif, D. B., \& Arpannudin, I. (2018). PPkn dan etika lingkungan hidup di sekolah adiwiyata.

Basri, B. (2018). Manajemen Kepala Sekolah Dalam Mewujudkan Sekolah Adiwiyata (Studi Kasus diI SD Negeri 02 Tanah Pak Lambik Kota Padang Panjang). al-fikrah: Jurnal Manajemen Pendidikan, 5(1), 101-112.

Dasrita, Y., Saam, Z., Amin, B., \& Siregar, Y. I. (2015). Kesadaran Lingkungan Siswa Sekolah Adiwiyata. Dinamika Lingkungan Indonesia, 2(1), 61-64. 


\section{Andina Wijayanti, Hasan Hariri, Dedy Hermanto Karwan, and Sowiyah}

Djafri, N. (2020). Pengaruh Gaya Kepemimpinan dan Budaya Kerja Kepala Sekolah di Pendidikan Anak Usia Dini. Jurnal Obsesi: Jurnal Pendidikan Anak Usia Dini, 4(2), 940-950.

Fitria, H., \& Samsia, S. (2020). Peran Kepala Sekolah Dalam Mewujudkan Program Sekolah Adiwiyata. JMKSP (Jurnal Manajemen, Kepemimpinan, dan Supervisi Pendidikan), 5(1), 84-91.

Hidayati, N. (2014). Perilaku Warga Sekolah Dalam Implementasi Adiwiyata di SMK Negeri 2 Semarang. Jurnal Geografi Gea, 14(1).

Khrisnamurti, D. A. (2019). Strategi Kepala Sekolah dalam Meningkatkan Standar Pendidik dan Tenaga Kependidikan di SMA Negeri 6 Samarinda. Tarbiyah Wa Ta'lim: Jurnal Penelitian Pendidikan dan Pembelajaran, 6(3), 191-199.

Kristiawan, M., Maryanti, N., \& Fitria, H. (2019). Membangun karakter peserta didik melalui green school di SMK Negeri 2 Muara Enim. JMKSP (Jurnal Manajemen, Kepemimpinan, dan Supervisi Pendidikan), 4(2), 210-217.

Landriany, E. (2015). Implementasi Kebijakan Adiwiyata Dalam Upaya Mewujudkan Pendidikan Lingkungan Hidup Pada Sekolah Menengah Umum (SMA) Kota Malang. University of Muhammadiyah Malang,

Lee, W. L., \& Burnett, J. (2008). Benchmarking energy use assessment of HK-BEAM, BREEAM and LEED. Building and environment, 43(11), 1882-1891.

Miranto, S. (2017). Integrasi Konsep-Konsep Pendidikan Lingkungan Hidup dalam Pembelajaran di Sekolah Menengah. Edusains, 9(1).

Mukminin, A. (2014). Strategi pembentukan karakter peduli lingkungan di sekolah adiwiyata mandiri. Ta'dib: Jurnal Pendidikan Islam, 19(02), 227-252.

Mulyana, R. (2009). Penanaman etika lingkungan melalui sekolah perduli dan berbudaya lingkungan. Jurnal Tabularasa, 6(2), 175-180.

Murniati, A., \& Harun, C. Z. (2015). Strategi Kepala Sekolah dalam Peningkatan Mutu di SD Negeri 1 Peukan Bada Aceh Besar. Jurnal Administrasi Pendidikan: Program Pascasarjana Unsyiah, 3(3).

Olsson, D. (2018). Student sustainability consciousness: Investigating effects of education for sustainable development in Sweden and Beyond. Karlstads universitet,

Oskamp, S. (2000). A sustainable future for humanity? How can psychology help? American Psychologist, 55(5), 496.

Pradini, I. K., Sudjanto, B., \& Nurjannah, N. (2018). Implementasi program sekolah adiwiyata dalam peningkatan mutu pendidikan di SDN Tanah Tinggi 3 Kota Tangerang. Jurnal Green Growth Dan Manajemen Lingkungan, 7(2), 122-132.

Purwanti, S. (2013). Peran kepemimpinan kepala sekolah dalam meningkatkan disiplin kerja guru dan pegawai di SMA Bakti Sejahtera Kecamatan Kongbeng Kabupaten Kutai Timur. Journal Administrasi Negara, 1(1), 210-224.

Quin, J., Deris, A., Bischoff, G., \& Johnson, J. T. (2015). Comparison of transformational leadership practices: Implications for school districts and principal preparation programs. Journal of Leadership Education, 14(3).

Rahmawati, I., \& Suwanda, I. M. (2015). Upaya Pembentukan Perilaku Peduli Lingkungan Siswa Melalui Sekolah Adiwiyata Di SMP Negeri 28 Surabaya. Jurnal kajian Moral dan Kewarganegaraan, 1, 71-78.

Rezkita, S., \& Wardani, K. (2018). Pengintegrasian Pendidikan Lingkungan Hidup Membentuk Karakter Peduli Lingkungan Di Sekolah Dasar. TRIHAYU: Jurnal Pendidikan Ke-SD-an, 4(2).

Rosyadi, Y. I., \& Pardjono, P. (2015). Peran kepala sekolah sebagai manajer dalam meningkatkan mutu pendidikan di smp 1 cilawu garut. Jurnal Akuntabilitas Manajemen Pendidikan, 3(1), 124-133. 
Setiyati, S. (2014). Pengaruh kepemimpinan kepala sekolah, motivasi Kerja, dan budaya sekolah terhadap kinerja guru. Jurnal Pendidikan Teknologi dan Kejuruan, 22(2), 200-206.

Sriwahyuni, E., Kristiawan, M., \& Wachidi, W. (2019). Strategi Kepala Sekolah Dalam Mengimplementasikan Standar Nasional Pendidikan (SNP) Pada SMK Negeri 2 Bukittinggi. JMKSP (Jurnal Manajemen, Kepemimpinan, dan Supervisi Pendidikan), 4(1), 21-33.

Suriansyah, A. (2015). Strategi kepemimpinan kepala sekolah, guru, orang tua, dan masyarakat dalam membentuk karakter siswa. Jurnal cakrawala pendidikan, 34(2).

Tim Adiwiyata Tingkat Nasional. (2011). Panduan Adiwiyata Sekolah Peduli dan Berbudaya Lingkungan. Kerjasama Kementerian Lingkungan Hidup dengan Kementerian Pendidikan dan Kebudayaan.

Widyaningrum, R. (2016). Pembentukankarakter Peduli Lingkungan Siswa Sekolah Dasar Melalui Sekolah Peduli Dan Berbudaya Lingkungan. Widya Wacana: Jurnal Ilmiah, $11(1)$.

Wuryandari, A., \& Akmaliyah, M. (2016). Game interaktif mencegah terjadinya pemanasan global untuk anak. Simetris: Jurnal Teknik Mesin, Elektro dan Ilmu Komputer, 7(1), 311-320 